УДК 619:616.99

(C) 2013

Березовський А. В., доктор ветеринарних наук, професор

НВФ «Бровафарма», м. Бровари Київської області

Галат М. В., кандидат ветеринарних наук

Національний університет біоресурсів і природокористування України

Небещук Л. В., Рибальченко Д. Ю., лікарі ветеринарної медццини

Українська лабораторія якості і безпеки продукції АПК

\title{
ЕПІЗООТОЛОГІЯ ТА ДІАГНОСТИКА ТОКСОПЛАЗМОЗУ КІЗ
}

\section{Рецензент - доктор ветеринарних наук В. О. Свстаф'єва}

Наведені дані результатів щзодо застосування різних тест-систем для зажиттєвої діагностики токсоплазмозу кіз. Встановлено особливості перебігу інвазії в залежності від сезону року, а також віку, статі та породи тварин. Зараженість молодняку кіз до одного року становила $10 \%$, у той час як у тварин віком від n'яти до шести років цей показник збільшувався й дорівнював 30 \%. Максимальну зараженість токсоплазмами реєстрували у тварин регіональних порід. Екстенсивність інвазіі з-поміж самок кіз була значно вищою (72,2\%) у порівнянні з самияли (20\%).

Ключові слова: кози, токсоплазмоз, тестсистеми, імуноферментний аналіз.

Постановка проблеми. Токсоплазмоз - поширена на земній кулі хвороба тварин та людини $[2,3]$. Безстатевий розвиток токсоплазм (тканинна фаза) відбувається в органах проміжних хазяїв - людини, ссавців і птахів. Представники родини котячих $\epsilon$ дефінітивними хазяями Toxoplasma gondii [4]. В ї організмі відбувається статевий цикл розвитку паразита 3 утворенням цист, які виділяються з фекаліями у зовнішнє середовище. Ооцисти тривалий час (близько 18 місяців) зберігаються в об'єктах довкілля й спричиняють інвазування паразитичними організмами людини і тварин. Окрім того одним із основних джерел зараження м'ясоїдних тварин $€$ вживання ними м'яса 3 цистами токсоплазм.

Аналіз основних досліджень i публікацій, у яких започатковано розв'язання проблеми. Людина нерідко заражається збудником токсоплазмозу в разі вживання в їжу м'ясних продуктів, що були недостатньо термічно обробленими $[9,10]$. У природних вогнищах хвороба зареєстрована практично в усіх видів ссавців і птахів. Особливо висока інвазованість токсоплазмами гризунів [1].

$\mathrm{y}$ синантропних вогнищах джерелом інвазії $\epsilon$ велика рогата худоба, вівці, кози, верблюди, коні, віслюки, свині, м'ясоїдні тварини, качки, гуси, ін- дики, цесарки, папуги та інші тварини. В Сгипті у процесі дослідження фекалій у $41,3 \%$ безпритульних котів виявлені ооцисти токсоплазм. У Сенегалі $30 \%$ великої рогатої худоби, $46 \%$ овець, $28 \%$ свиней і $6,2 \%$ кіз є носіями токсоплазм; антитіла до паразитичних організмів зареєстровані у $65,2 \%$ великої рогатої худоби Нігерії. Позитивно реагують на токсоплазмоз леви, зебри, бегемоти та інші тварини. В Індії $34 \%$ кіз і 31,5\% свиней уражені збудниками цієї хвороби; 73,7 \% верблюдів, 31,6 \% кіз, 21,4\% овець, 20,4\% буйволів Афганістану є носіями токсоплазм. У Бразилії 90,6\% котів, $60 \%$ биків, 68,4\% собак, 41,2\% курей, $40 \%$ качок, $24,7 \%$ свиней, $39 \%$ також овець уражені цими паразитами [1].

Тканинні цисти токсоплазм найчастіше виявляють у різних тканинах інвазованих свиней, овець та кіз. Цисти Toxoplasma gondii в оленині та іншому м'ясі диких тварин, у тому числі зайців, кабанів, кенгуру, ведмедів, залишається потенційним джерелом інвазії для людини [8]. Працівники забійних пунктів, м'ясники і мисливці можуть заразитися під час потрошіння та обробки м'яса.

Тканинні цисти менш стійкі до екологічних умов, аніж ооцисти. Вони залишаються інвазійними при $1-4{ }^{\circ} \mathrm{C}$ у тушах або м'ясному фарші впродовж трьох тижнів. Більшість тканинних цист гине за температури $-12{ }^{\circ} \mathrm{C}$ і нижче [5-7].

У овець та кіз токсоплазмоз $є$ основною причиною абортів і мертвонароджень. Повідомлення про серопозитивність тварин у різних країнах відрізняються. Останні публікації підтвердили, що серопозитивність тварин може бути досить високою [8].

Мета і завдання досліджень. Метою роботи було вивчення особливостей епізоотології токсоплазмозу кіз на території України. В завдання входило встановити особливості перебігу інвазії в залежності від сезону року, а також віку, статі та породи тварин. 
Матеріали і методи досліджень. Дослідження проводили впродовж 2010-2012 рр. на козах (приватне господарство «Золота коза» Новоархангельського району Кіровоградської області). Сироватку крові тварин досліджували за методом імуноферментного аналізу.

Для встановлення діагнозу від тварин відбирали венозну кров (від 2-х до 10-и мл) у стерильні одноразові пробірки. Одержану кров витримували протягом однієї години за кімнатної температури, після чого її переносили у холодильник на одну добу. Сироватку відбирали в одноразові пробірки типу «Епендорф» і центрифугували при 3000 обертів 10 хвилин. Доочищену сироватку зберігали у холодильнику за температури $+2 \ldots+4{ }^{\circ} \mathrm{C}$ до проведення досліджень.

Для досліджень сироваток крові кіз використовували наступні тест-системи: набір реагентів D1764 для імуноферментного виявлення сумарних антитіл до Toxoplasma gondii «ВектоТоксоантитіла» (виробник - ЗАТ «Вектор-бест», Новосибірськ, Російська Федерація) та антиген (Antigen suspension, виробник - «Medicago», Швеція), вугільну суспензію (Carbon suspension, india ink, виробник - «Medicago») та три різні контрольні сироватки крові, зокрема, позитивну й негативну.

Для встановлення динаміки ураженості кіз збудником T. gondii залежно від їх віку було сформовано 3 групи тварин: молодняк до одного року, від трьох до п'яти та від п’яти до шести років.

Результати досліджень. Із 76 досліджених на фермі «Золота коза» тварин позитивно прореагували в процесі постановки реакції імуноферментного аналізу на наявність титрів антитіл до збудника токсоплазмозу 33 , що становить $43,42 \%$, сумнівно - 2 тварини $(2,63 \%)$. Останні дослідні зразки $(53,95 \%)$ виявилися негативними.
Токсоплазмоз кіз, за даними літературних джерел, належить до інвазій, що не має чітко вираженої сезонності. Проте, проводячи досліджння, ми зафіксували інші результати: встановлено, що екстенсивність інвазії серед тварин взимку становила $20 \%$, навесні - 60,87\%, влітку $-85,71 \%$, а восени $-37,49 \%$ [3].

Результати досліджень тварин господарства свідчать про різні показники екстенсивності інвазії впродовж року. Саме тому нами було проведено серологічне дослідження сироваток крові двох котів, які знаходилися на території ферми i, ймовірно, могли бути джерелом інвазії для кіз.

За результатами проведеної роботи встановлено, що рівень титрів антитіл одного 3 котів становив 2,518 одиниць оптичної густини, а іншого - 3,205 одиниць ОГ. До того ж контрольні зразки тестсистеми прореагували наступним чином: сильнопозитивний контрольний зразок $-3,201$ одиниць ОГ; слабопозитивний - 0,742 одиниць ОГ; негативний $-0,121$ одиниць ОГ (див. рис.).

Результати проведених серологічних досліджень сироваток крові котів свідчать про наявність високих титрів антитіл до збудника T. gondii. Це, очевидно, співпадає з гострим перебігом хвороби та з виділенням ооцист у навколишнє середовище. Останнє й може виступати джерелом інвазії для тварин та людини.

Результати досліджень свідчать про збільшення екстенсивності токсоплазмозної інвазії з віком тварин. Так, зараженість молодняку кіз до одного року становила $10 \%$, в той час як у тварин віком від п'яти до шести років уже $30 \%$, що на $20 \%$ більше. Це, 3 нашого погляду, пов'язано 3 тим, що чим старша тварина, тим більшою $\epsilon$ ймовірність зараження іiі збудником T. gondii.

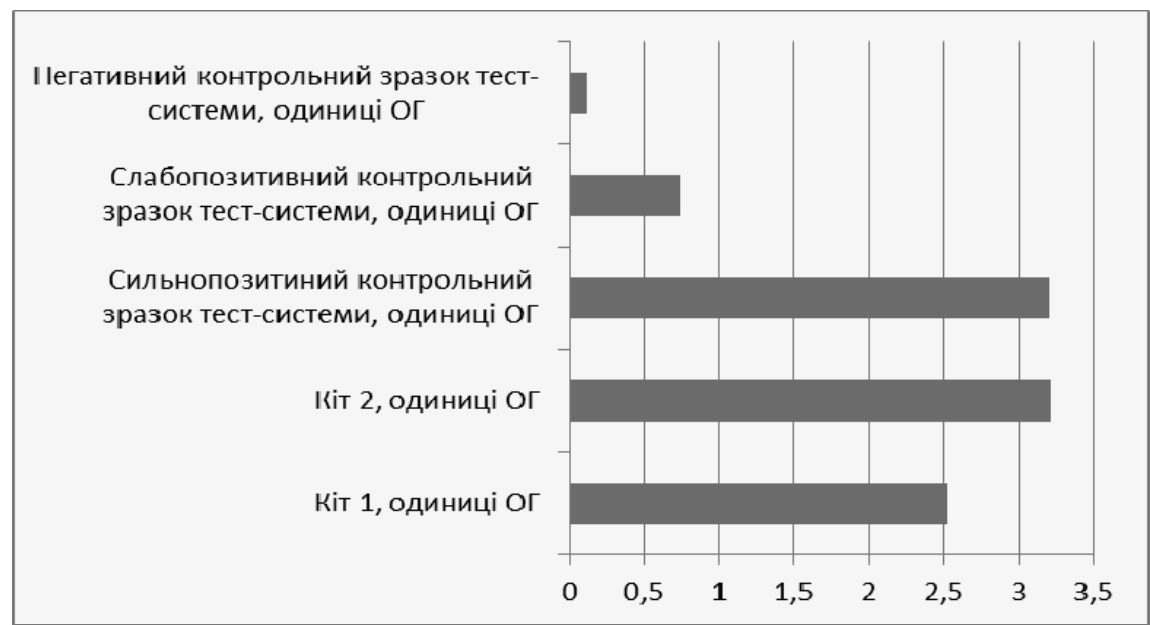

Рис. Порівняння одиниць оптичної густини сироватки крові двох котів та контрольних зразків тест-системи 
Крім того нами були встановлені рівні титрів антитіл по групах залежно від віку тварин: piвень титрів антитіл у молодняку кіз становив 0,794 одиниць ОГ, у дугій групі тварин - 3,159 одиниць ОГ і у третій - 1,881 одиниці ОГ. Таким чином, найвищий рівень був виявлений у тварин віком від трьох до п'яти років, що може співпадати 3 періодом перебігу гострої стадії інвазії. Цей показник зменшується у групі тварин у віці від п'яти до шести років, що може бути пов'язано з переходом гострої стадії перебігу токсоплазмозу у хронічну форму.

У наступній серії дослідів було проведено визначення ступеню ураженості збудником токсоплазмозу залежно від породи кіз та місць, звідки вони були завезені.

У ході досліджень було встановлено тенденцію до максимальної зараженості токсоплазмами тварин регіональних порід. Так, серед кіз, завезених із Криму, у 2011 році екстенсивність інвазії сягала $100 \%$, а найвищий показник у тварин зааненської породи становив лише $20 \%$.

Для встановлення динаміки ураженості кіз залежно від їх статі було проведено аналіз зразків сироваток крові. За результатами проведених досліджень встановлено, що екстенсивність інвазії з-поміж самок кіз була суттєво вищою (72,2\%) у порівнянні з самцями $(20 \%)$. Значно меншу інвазованість самців серед досліджених тварин можна пояснити їх відокремленим утри-

\section{БІБЛІОГРАФІЯ}

1. Галат В. Ф. Тропическая ветеринарная паразитология / В. Ф. Галат // К. : Вища школа. 1986. $-272 \mathrm{c}$.

2. Галат М. В. Рекомендації з діагностики та заходів боротьби 3 токсоплазмозом тварин / М. В. Галат, Д. Б. Гончаров, Т. О. Суботенко [та ін.] // Методичні рекомендації для бакалаврів, магістрів та спеціалістів ветеринарної медицини. К. : ЦП «Компринт». - 2012. - 22 с.

3. Новак М. Д. Модель паразитарной системы «Toxoplasma gondii - животные, люди» / М. Д. Новак, А. И. Новак // Ветеринария сельскохозяйственных животных. - 2006. - № 10. - С. 14.

4. Тимофеев Б. А. Токсоплазмоз кошек / Б. А. Тимофеев, С. Н. Олейников // Ветеринария сельскохозяйственных животных. - 2006. - № 10. C. $9-13$.

5. Grossklaus D. Die Uberlebensdauer von ToxoplasmaCysten in Schweinefleisch Mitteilung: Ergebnisse von Lagerungsversuchen bei verschiedenen Temperaturen / D. Grossklaus. H.-J. Bau-mgarten // Fleischwirtschaft, 1968. - Vol. 48. - P. 930-932. манням і покращеними умовами годівлі. Водночас рівень титрів антитіл у самців мало відрізнявся від аналогічного показника у самок. Ці показники наближалися до значення сильно позитивного контрольного зразка $(3,201$ ООГ), що свідчить про імовірність гострого перебігу токсоплазмозу у тварин під час проведення досліджень.

\section{Висновки:}

1. У ході постановки реакції імуноферментного аналізу 43,42\% кіз позитивно реагують на наявність в їх організмі антитіл до збудника Toxoplasma gondii.

2. Токсоплазмозна інвазія реєструється у будьяку пору року. Максимальне ураження токсоплазмами виявлено у кіз віком від 5 до 6 років (30\%), що на $20 \%$ більше, ніж у тварин віком до одного року.

3. Для прижиттєвої діагностики токсоплазмозу кіз методом імуноферментного аналізу ефективними виявилися тест-система «ВектоТоксоантитіла» фірми «ВекторБест» (Російська Федерація) та метод вуглецевого серологічного аналізу, виробником антигену і вугільної суспензії якого є шведська фірма «Medicago».

Перспективними аспектами досліджень $\epsilon$ вивчення питань поширення в Україні токсоплазмозу серед інших видів тварин та розробка заходів боротьби з цією інвазією.

6. Kotula A. W. Effect of freezing on infectivity of Toxoplasma gondii tissue cysts in pork / A. W. Kotula, J. P. Dubey, A. K. Sharar, C. D. Andrews, S. K. Shen, D. S. Lindsay // J. Food Prot., 1991. - Vol. 54. - P. 687-690.

7. Kuticic $V$. Studies of the effect of various treatments on the viability of Toxoplasma gondii tissue cysts and oocysts / V. Kuticic, T. Wikerhauser // In: Gross U., editor. Toxoplasma gondii. - Berlin: Springer-Verlag, 1996. - P. 261-265.

8. Tenter A. M. Toxoplasma gondii: from animals to humans / A. M. Tenter, A. R. Heckeroth, L. M. Weiss // Int. J. Parasitol., 2000. - Vol. 30. - P. 1217-1258.

9. Villari $S$. Risk factors for toxoplasmosis in pigs bred in Sicily, Southern Italy / S. Villari, G. Vesco, E. Petersen, A. Crispo, W. Buffolano // Vet. Parasitol., 2009. - № 161. - P. 1-8.

10. Zimmerman J. J. Prevalence of toxoplasmosis in swine from Iowa / J. J. Zimmerman, D. W. Dreesen, W. J. Owen, G. W. Beran // J. Am. Vet. Med. Assoc. 1990. - № 196. - P. 266-270. 